\title{
ANALISIS PERAN PEMUNGUTAN PAJAK PARKIR DALAM PENINGKATAN PENDAPATAN ASLI DAERAH DI KOTA BITUNG
}

\author{
Selin Gintoe ${ }^{1}$, Inggriani Elim², Lidia M. Mawikere ${ }^{3}$ \\ 1,2,3 Jurusan Akuntansi, Fakultas Ekonomi Dan Bisnis, Universitas Sam Ratulangi, Jl.Kampus Bahu, Manado, \\ 95115, Indonesia
}

Email : gintoeselin@gmail.com

\begin{abstract}
The source of the Regional Original Revenue is local tax, one of which is parking tax. In this study, it was described how the practice of parking tax collection, parking tax collection function, contribution and participation in increasing the original regional income of Bitung City, while the research method used was using a qualitative descriptive approach. One source of funds that comes from regional capacity itself is Regional Original Revenue. From the results of this study indicate that the contribution of Parking Tax to support the Original Revenue of Bitung City in 2015-2017 tends to decrease. In 2015 where parking tax had the highest contribution of $152.89 \%$ and the low contribution can be seen in 2017 which was $89.17 \%$. The decrease in the contribution of parking tax was due to several causes, namely in fulfilling the taxation regulations that apply to taxpayers lacking a good understanding so that taxpayers have the awareness to pay their due taxes, found several new parking spaces and it is known that they have not been registered as regional taxpayers In addition, there is income from a parking lot whose income cannot be estimated so that the parking lot does not pay the due tax.
\end{abstract}

Keywords : Collection, Parking Tax and Local Revenue

\section{PENDAHULUAN}

Untuk membiayai pembangunan suatu daerah peranan Pajak Parkir sangat diperlukan dalam Pendapatan Asli Daerah, seperti diketahui bahwa parkir merupakan suatu jenis usaha yang dapat memberikan penghasilan dalam penerimaan daerah. Parkir juga sangat dibutuhkan untuk mengatur, menjaga keamanan dan kenyamanan kendaraan pada suatu tempat. Dan untuk mengatur pendapatan dari potensi pajak parkir guna untuk meningkatkan Pendapatan Asli Daerah maka perlu dibuatkan Peraturan Daerah atau Undang-Undang dan dilaksanakan sesuai dengan ketentuan yang berlaku (Intan, 2016). Penetapan tarif Pajak Parkir sebesar $15 \%$ sesuai dengan Peraturan Daerah Kota Bitung. Lokasi atau tempat pemungutan Pajak Parkir di Kota Bitung yaitu terdapat di TK Girian Jaya, Kentucky Fried Chicken (KFC), RS. Budi Mulia, Centrepark Citiemart, dan Centrepark RSUD. Tujuan yang ingin dicapai dari penelitian ini adalah untuk mengetahui bagaimana peran pemungutan pajak parkir oleh Badan Pengelola Pajak dan Retribusi Daerah Kota Bitung terhadap Pendapatan Asli Daerah Kota Bitung.

\section{TINJAUAN PUSTAKA}

Konsep Akuntansi. Untuk dapat melihat perbedaan dan persamaan mengenai apa yang akan dicapai oleh perusahaan dan sebagai bahan pembanding dengan perusahaan lain yang sejenis maka harus mengikuti prinsip-prinsip akuntansi yang ditetapkan sebagaimana mestinya (Irsan, $2014: 2$ ).

Konsep Akuntansi Perpajakan. Transaksi menandakan awal dari proses akuntansi dimana transaksi dapat menyebabkan perubahan pada laporan posisi keuangan suatu perusahaan. 
transaksi tersebut dapat dijadikan panutan bagi pemerintah dalam membuat peraturanperaturan perpajakan sehingga pemungutan pajak di Indonesia bisa berjalan dengan baik yang berguna untuk meningkatkan pembanguna di Indonesia. Dengan adanya hubungan antara akuntansi dan pajak inilah, yaitu transaksi, yang dikenal dengan istilah Akuntansi Pajak yaitu perusahaan menerapkan akuntansi yang sudah sesuai dengan peraturan pajak yang berlaku (Irsan, $2014: 2$ ).

Konsep Pajak Daerah. Undang-Undang Nomor 28 Tahun 2009 tentang Pajak Daerah dan Retribusi Daerah yang menjadi dasar hukum sistem pemungutan Pajak Daerah. Seperti diketahui bahwa salah satu pendapatan daerah yang penting yaitu pajak daerah yang digunakan untuk membiayai pembangunan suatu daerah.

Konsep Pajak Parkir. Pajak Parkir adalah salah satu jenis usaha yang dikenakan pajak atas penyediaan lokasi parkir diluar badan jalan oleh orang pribadi atau badan, baik yang disediakan berkaitan dengan jenis usaha tersebut.

\section{Penelitian Terdahulu}

1. Rosalina (2016) Peran Pemungutan Pajak Parkir Dalam Peningkatan Pendapatan Asli Daerah di Kota Malang. Hasil penelitian yaitu suatu praktik pemungutan Pajak Parkir di Kota Malang sebagaimana telah dilakukan dan terlaksana dengan baik dan benar sesuai dengan ketentuan dan peraturan perundang-undangan yang telah ditetapkan sebagaimana mestinya dalam hal ini dilaksanakan dengan mengikuti Undang-undang Pajak Daerah Nomor 28 Tahun 2009.

2. Havic (2016) Analisis Penerimaan Retribusi Parkir dan Pajak Parkir di Dinas Pendapatan Asli Daerah Kota Palembang. Hasil penelitian yaitu terjadi peningkatan pendapatan Pajak Parkir dari tahun 2011-2016 dan telah melampaui dari target yang telah ditetapkan sehingga Pajak Parkir memberikan kontribusi pada Pendapatan Asli Daerah Kota Palembang.

3. Intan (2016) Akuntansi Penerimaan Pajak Parkir Dan Retribusi Parkir di Kabupaten Malang. Hasil penelitian yaitu penyusunan dan penyajian akuntansi untuk mencatat transaksi pendapatan Pajak Parkir pada Kantor DPPKA Kabupaten Malang dan Retribusi Parkir pada Kantor DPKI Kabupaten Malang dari Tahun 2012-2014 sesuai pada SAKD yang berlandaskan Pemendagri Nomor 13 Tahun 2006.

\section{METODE PENELITIAN}

Jenis Penelitian. Metode penelitian kualitatif digunakan untuk mengolah data yang didapatkan secara akurat yang memiliki makna yang mendalam dimana makna tersebut adalah data yang sebenarnya dan pasti yang memiliki suatu nilai dari data yang tampak. Sehingga dalam hal ini maknalah yang menekankan pada suatu penelitian kualitatif Sugiyono (2016 : 1). Penelitian ini menggunakan jenis penelitian deskriptif dengan mengumpulkan data-data penelitian yang diperoleh dari Badan Pengelola Pajak dan Retribusi Daerah Kota Bitung mengenai permasalahan penelitian.

Tempat Dan Waktu Penelitian. Tempat penelitian dilakukan pada Badan Pengelola Pajak dan Retribusi Daerah Kota Bitung. Jln. Dr. Sam Ratulangi No. 45 Bitung, Provinsi Sulawesi Utara. Periode pengamatan untuk hasil penelitian dimulai pada bulan April 2018 sampai dengan bulan Juni 2018.

\section{Prosedur Penelitian}

1. Merumuskan masalah dengan baik dan harus jelas.

2. Teori-teori yang ditetapkan menjadi patokan dan pada buku teks maupun penelitian terdahulu.

3. Dalam pencarian data agar dilakukan dengan cara yang benar dan sesuai. 
4. Data yang didapatkan dan dikumpulkan untuk selanjutnya bisa diolah dalam bentuk tabel, grafik dan statistik guna memberikan informasi yang seharusnya dan dapat dijadikan acuan untuk penelitian selanjutnya.

\section{Jenis, Sumber Dan Metode Pengumpulan Data}

\section{Data Kuantitaf}

Data yang menggunakan unsur angka dan bilangan dengan tujuan untuk dapat mendeskripsikan berbagai kejadian yang berhubungan dengan penelitian yang dilakukan. Dalam penelitian ini data kuantitatif yang digunakan berupa laporan rekapitulasi target dan realisasi Pendapatan Asli Daerah Kota Bitung dari Tahun 2015-2017.

2. Data Kualitatif

Data kualitatif merupakan kumpulan data yang dapat diuraikan secara deskriptif yang berhubungan dengan tanggapan atau informasi dari narasumber. Dalam penelitian ini data kualitatif yang digunakan berupa data-data yang berasal dari hasil wawancara dengan Kepala Bagian Pajak Daerah.

Didalam penelitian ini, penulis menggunakan data kualitatif yang sebagai acuan untuk mengetahui bagaimana peran pemungutan Pajak Parkir dalam meningkatkan Pendapatan Asli Daerah di Kota Bitung.

Adapun sumber data yang penulis gunakan didalam penelitian ini adalah data primer dan sekunder. Yang dimana penelitian menggunakan data primer yaitu dilihat berdasarkan dari hasil wawancara secara langsung tentang peran pemungutan pajak parkir untuk menunjang pendapatan asli daerah di Kota Bitung. Sedangkan perbedaannya dengan data sekunder yaitu berupa informasi-informasi yang berkaitan langsung dengan lembaga pemerintahan serta dengan tambahan mempelajari dan memahami dari berbagai macam sumber yang ada seperti buku, internet, dan berbagai jenis penelitian baik dalam jurnal maupun skripsi yang ada kaitannya dengan penelitian tersebut. Untuk memperoleh data yang diperlukan dalam penelitian ini, maka metode pengumpulan data yang digunakan adalah :

1. Observasi

Observasi atau pengamatan pada objek penelitian. Observasi dilakukan denga tujuan untuk mendapatkan data yang lebih akurat dan lengkap. Observasi yang digunakan dalam penelitian ini adalah Observasi Partisipatif, dalam observasi ini, peneliti turun langsung ke lapangan atau terlibat dengan kegiatan sehari-hari orang yang sedang diamati atau yang digunakan sebagai sumber data penelitian Sugiyono (2016 : 64). Dalam hal ini peneliti melakukan pengamatan langsung terhadap aktivitas pegawai pada Badan Pengelola Pajak dan Retribusi Daerah Kota Bitung.

2. Wawancara

Metode ini digunakan untuk memperoleh data yang berkaitan dengan pajak parkir di Kota Bitung. Dalam hal ini narasumber yang diwawancarai adalah orang-orang yang berkaitan langsung dengan penelitian yang akan dilakukan, diantaranya yaitu:

a. Sekretaris Badan Pengelolah Pajak dan Retribusi Daerah Kota Bitung

b. Kepala bagian Pajak Daerah

c. Kepala bidang Pajak Parkir

Adapun pertanyaan yang akan ditanyakan dalam wawancara dengan responden diantaranya membahas tentang :

1. Target dan realisasi Pajak Parkir Kota Bitung pada Tahun 2015-2017.

2. Target dan realisasi Pendapatan Asli Daerah Kota Bitung pada Tahun 2015-2017.

3. Pendapatan Pajak Daerah di Kota Bitung dari Tahun2015-2017.

4. Kontribusi Pajak Parkir terhadap Pendapatan Asli Daerah Kota Bitung. 
Metode Analisis. Untuk menganalisis Pendapatan Asli Daerah yang diterima oleh Badan Pengelola Pajak dan Retribusi Daerah Kota Bitung dalam pemungutan Pajak Parkir. Dalam hal ini dokumen yang perlu di analisis dalam pengumpulan data-data yang berkaitan dengan Pajak Parkir, antara lain :

1. Menghitung Target dan Realisasi Pajak Parkir Kota Bitung Tahun 2015-2017.

2. Menghitung Target dan Realisasi untuk Pendapatan Asli Daerah Kota Bitung Tahun 2015-2017.

3. Menghitung Pendapatan Pajak Daerah di Kota Bitung tahun 2015-2017.

4. Menganalisis kontribusi Pajak Parkir untuk menunjang Pendapatan Asli Daerah Kota Bitung Tahun 2015-2017.

\section{HASIL PENELITIAN DAN PEMBAHASAN}

\subsection{Hasil Penelitian}

Menghitung Target dan Realisasi Pajak Parkir Kota Bitung Tahun 2015-2017.

Berdasarkan data yang diperoleh dari Badan Pengelola Pajak dan Retribusi Daerah Kota Bitung diketahui bahwa Pajak Parkir memberikan kontribusi yang sangat kecil dalam meningkatkan Pendapatan Asli Daerah Kota Bitung. Pada Tabel berikut ini terlihat bahwa target dan realisasi Pajak Parkir dari Tahun 2015 sampai dengan Tahun 2017 mengalami peningkatan. Dari data yang diperoleh, dapat dihitung berdasarkan tabel berikut :

Tabel 1. Target dan Realisasi Pajak Parkir di Kota Bitung Pada Tahun 2015-2017

\begin{tabular}{ccccc}
\hline \multirow{2}{*}{ TAHUN } & \multicolumn{2}{c}{ TARGET } & \multicolumn{2}{c}{ REALISASI } \\
\cline { 2 - 5 } & $\begin{array}{c}\text { APBD INDUK } \\
(\mathbf{R p})\end{array}$ & $\begin{array}{c}\text { APBD PERUBAHAN } \\
(\mathbf{R p})\end{array}$ & $\begin{array}{c}\text { 05 Jan-15 Des } \\
(\mathbf{R p})\end{array}$ & $\begin{array}{c}\text { 16 Des-30 Des } \\
(\mathbf{R p})\end{array}$ \\
\hline 2015 & 25.000 .000 & 15.000 .000 & 20.615 .700 & 2.317 .200 \\
2016 & 15.000 .000 & 20.000 .000 & 21.931 .500 & 1.050 .000 \\
2017 & 30.000 .000 & 35.000 .000 & 24.571 .300 & 6.639 .150 \\
\hline
\end{tabular}

Sumber : Rincian Target dan Realisasi Pajak Parkir Kota Bitung Tahun 2015-2017 pada Badan Pengelola Pajak dan Retribusi Daerah Kota Bitung.

Menghitung Target dan Realisasi Pendapatan Asli Daerah Kota Bitung Tahun 20152017

Tabel 2. Target dan Realisasi Pendapatan Asli Daerah Kota Bitung Pada Tahun 20152017

\begin{tabular}{ccc}
\hline TAHUN & \multicolumn{2}{c}{ PENDAPATAN ASLI DAERAH } \\
& TARGET $($ Rp) & REALISASI (Rp) \\
\hline 2015 & 15.000 .000 & 22.932 .900 \\
2016 & 20.000 .000 & 22.981 .500 \\
2017 & 35.000 .000 & 31.210 .450 \\
\hline
\end{tabular}

Sumber : Rincian Target dan Realisasi dalam Pendapatan Asli Daerah Kota Bitung Tahun 2015-2017 pada Badan Pengelola Pajak dan Retribusi Daerah Kota Bitung. 
Menghitung Pendapatan Pajak Daerah di Kota Bitung Tahun 2015-2017

Tabel 3. Laporan Target dan Realisasi Pajak Daerah Pada Badan Pengelola Pajak dan Retribusi Daerah Kota Bitung pada Tahun 2015-2017

\begin{tabular}{|c|c|c|c|c|c|c|}
\hline \multirow{2}{*}{ JENIS PAJAK } & \multicolumn{2}{|c|}{2015} & \multicolumn{2}{|c|}{2016} & \multicolumn{2}{|c|}{2017} \\
\hline & TARGET & REALISASI & TARGET & REALISASI & TARGET & REALISASI \\
\hline HOTEL & 1.500 .000 .000 & 1.695 .607 .242 & 1.627 .000 .000 & 2.077 .088 .894 & 1.800 .000 & 980.304 .084 \\
\hline RESTORAN & 1.950 .000 .000 & 2.606 .105 .174 & 2.150 .000 .000 & 2.623 .122 .477 & 2.500 .000 .000 & 1.310 .531 .223 \\
\hline HIBURAN & 250.000 .000 & 286.354 .750 & 300.000 .000 & 353.565 .459 & 500.000 .000 & 258.838 .453 \\
\hline REKLAME & 800.000 .000 & 836.869 .454 & 750.000 .000 & 1.130 .347 .349 & 800.000 .000 & 686.515 .919 \\
\hline PENERANGAN JALAN & 13.630 .000 .000 & 12.829 .757 .492 & 12.500 .000 .000 & 12.522 .804 .740 & 12.500 .000 .000 & 8.910 .265 .707 \\
\hline MINERAL BUKAN LOGAM & 300.000 .000 & 671.637 .571 & 300.000 .000 & 505.573 .490 & 500.000 .000 & 191.393 .708 \\
\hline PARKIR & 15.000 .000 & 22.932 .900 & 20.000 .000 & 22.981 .500 & 30.000 .000 & 56.455 .095 \\
\hline AIR TANAH & 900.000 .000 & 1.315 .038 .395 & 1.100 .000 .000 & 1.450 .656 .022 & 1.400 .000 .000 & 532.812 .927 \\
\hline SARANG BURUNG WALET & 5.000 .000 & 4.100 .000 & 3.000 .000 & 4.100 .000 & 5.000 .000 & 1.500 .000 \\
\hline PBB-P2 & 9.000 .000 .000 & 10.837 .187 .754 & 10.000 .000 .000 & 10.113 .127 .165 & 10.000 .000 .000 & 2.460 .897 .829 \\
\hline BPHTB & 4.000 .000 .000 & 6.254 .509 .434 & 3.000 .000 .000 & 4.649 .941 .153 & 4.965 .000 .000 & 2.860 .355 .300 \\
\hline JUMLAH & 32.350.000.000 & 37.360 .100 .176 & 32.350 .000 .000 & 35.463.308.240 & 35.000 .000 .000 & 18.240 .870 .245 \\
\hline
\end{tabular}

Sumber : Rincian Target dan Realisasi Pajak Daerah Kota Bitung Tahun 2014-2017 pada Badan Pengelola Pajak dan Retribusi Daerah Kota Bitung.

Menganalisis Kontribusi Pajak Parkir Terhadap Pendapatan Asli Daerah Kota Bitung Tahun 2015-2017

Tabel 4. Kontribusi Pajak Parkir terhadap Pendapatan Asli Daerah Kota Bitung Tahun 2015-2017.

\begin{tabular}{cccr}
\hline TAHUN & $\begin{array}{c}\text { REALISASI PAJAK } \\
\text { PARKIR (Rp) }\end{array}$ & $\begin{array}{c}\text { PENDAPATAN ASLI } \\
\text { DAERAH (Rp) }\end{array}$ & $\begin{array}{c}\text { KONTRIBUSI } \\
(\boldsymbol{\%})\end{array}$ \\
\hline 2015 & 15.000 .000 & 22.932 .900 & $152,89 \%$ \\
2016 & 20.000 .000 & 22.981 .500 & $114,91 \%$ \\
2017 & 35.000 .000 & 31.210 .450 & $89,17 \%$ \\
\hline
\end{tabular}

Sumber : Data Pada Badan Pengelola Pajak dan Retribusi Daerah Kota Bitung pada Tahun 2015-2017

Pada tabel diatas dapat dilihat tingkat kontribusi Pajak Parkir terhadap Pendapatan Asli Daerah Kota Bitung tahun 2015-2017 mengalami penurunan. Kontribusi tertinggi terjadi pada tahun 2015 yaitu sebesar $152,89 \%$ dan penurunan kontribusi terendah terjadi pada tahun 2017 yaitu sebesar $89,17 \%$.

\subsection{Pembahasan}

Target dan Realisasi Pajak Parkir Kota Bitung Tahun 2015-2017. Berdasarkan Tabel diatas target Pajak Parkir Kota Bitung dari tahun 2015-2017 yang ditetapkan selalu mengalami fluktuasi atau naik turun dari tahun ke tahun. Target Pajak Parkir pada Tahun 2015 mencapai Rp. 20.000.000 APBD Induk dan Rp. 15.000.000 APBD Perubahan, sedangkan pada Tahun 2016 target Pajak Parkir mengalami penurunan pada APBD Induk sebesar Rp. 15.000.000 tetapi mengalami peningkatan pada APBD Perubahan sebesar Rp. 20.000.000 dan target Pajak Parkir Tahun 2017 mengalami peningkatan sebesar Rp. 30.000.000 APBD Induk dan Rp. 35.000.000 APBD Perubahan. Untuk meningkatkan potensi Pajak Parkir di Kota Bitung setiap tahunnya adanya penetapan target yang lebih besar. Peningkatan target dari Tahun 2015 sampai dengan Tahun 2017 diikuti dengan pencapaian realisasi Pajak Parkir yang diterima. Jika dilihat berdasarkan dari jumlah realisasinya, diperoleh bahwa pendapatan Pajak Parkir mengalami peningkatan dengan satu kali terjadi penurunan yaitu pada Tahun 2016. Perolehan realisasi Pajak Parkir yang diterima di tahun 2015 mencapai Rp. 20.615.700 per tanggal 05 Januari-15 Desember dan Rp. 2.317.200 per tanggal 16 Desember-31 Desember, sedangkan perolehan realisasi Pajak Parkir di tahun 2016 
mencapai Rp. 21.931.500 per tanggal 05 Januari-15 Desember dan mengalami penurunan per tanggal 16 Desember-31 Desember sebesar Rp. 1.060 .000 pada Tahun 2017 realisasi Pajak Parkir mengalami peningkatan mencapai Rp. 24.571.300 per tanggal 05 Januari-15 Desember dan Rp. 6.639.150 per tanggal 16 Desember-31 Desember peningkatan realisasi Pajak Parkir Tahun 2017 terjadi dikarenakan kenaikan pada target Pajak Parkir pada Tahun 2017. Meningkat dan menurunnya target dan realisasi Pajak Parkir di Kota Bitung dapat berdampak terhadap Pendapatan Asli Daerah Kota Bitung.

\section{Target dan Realisasi Pendapatan Asli Daerah Kota Bitung Tahun 2015-2017.} Berdasarkan Tabel diatas target dan realisasi untuk Pendapatan Asli Daerah Kota Bitung pada Tahun 2015-2017 yang ditentukan terus mengalami kenaikkan untuk setiap tahunnya. Pada Tahun 2015 target Pendapatan Asli Daerah mencapai Rp. 15.000.000 dan realisasi Pendapatan Asli Daerah mencapai Rp. 22.932.900. Target dan realisasi untuk Pendapatan Asli Daerah Kota Bitung pada Tahun 2016 mengalami kenaikkan mencapai Rp. 20.000.000 dan Rp. 22.981.500 dan kembali terjadi kenaikkan pada Tahun 2017 target Pendapatan Asli Daerah mencapai Rp. 30.000 .000 dan realisasi Pendapatan Asli Daerah mencapai Rp. 41.210.450, dapat diketahui bahwa Pendapatan Asli Daerah Kota Bitung pada tahun 20152017 tiap tahunnya mengalami perubahan berupa kenaikkan.

Pendapatan Pajak Daerah di Kota Bitung Tahun 2015-2017. Berdasarkan Tabel diatas target dan realisasi Pajak Daerah Kota Bitung dari tahun 2015-2017 yang ditetapkan selalu mengalami fluktuasi atau naik turun dari tahun ke tahun. Pada Tahun 2015 mencapai Rp. 32.350.000.000 target Pajak Daerah dan Rp. 37.360.100.176 realisasi Pajak Daerah, sedangkan pada Tahun 2016 target Pajak Daerah tetap sebesar Rp. 32.350.000.000 tetapi mengalami penurunan pada realisasi Pajak Daerah sebesar Rp. 35.463.308.240, dan pada Tahun2017 target Pajak Daerah mengalami peningkatan sebesar Rp. 35.000.000.000 tetapi mengalami penurunan pada realisasi Pajak Daerah sebesar Rp. 18.240.870.245.

Kontribusi Pajak Parkir untuk menunjang Pendapatan Asli Daerah Kota Bitung Tahun 2015-2017. Pada Tabel diatas dapat dilihat bahwa menurunnya kontribusi dapat disebabkan karena beberapa penyebab yaitu dalam memenuhi peraturan perpajakan yang berlaku Wajib Pajak kurang memiliki pemahaman yang baik agar Wajib Pajak memiliki kesadaran untuk membayar pajak terutangnya, ditemukan adanya beberapa tempat Parkir yang baru dibuat dan diketahui bahwa belum didaftarkan sebagai Wajib Pajak Daerah, selain itu adanya pendapatan dari suatu tempat parkir yang pendapatannya tidak dapat diperkirakan sehingga tempat parkir tersebut tidak membayar pajak terutangnya. Untuk mengatasi penurunan kontribusi tersebut Badan Pengelola Pajak dan Retribusi Daerah Kota Bitung harus terus menerapkan metode-metode berupa tata cara pembayaran pajak terutang oleh Wajib Pajak dalam membayar pajak terutangnya menurut ketetapan perpajakan dan Undangundang yang berlaku dengan cara melakukan penyuluhan dan sosialisasi, serta untuk lokasilokasi parkir yang baru dibuat dan diketahui bahwa belum didaftarkan sebagai Wajib Pajak Daerah dilakukan peninjauan langsung ke lokasi parkir tersebut, dan Wajib Pajak yang sudah terdaftar harus dilakukan pengawasan secara rutin.

\section{KESIMPULAN DAN SARAN}

\subsection{Kesimpulan}

Berdasarkan hasil penelitian yang telah dilakukan, maka dapat diambil kesimpulan sebagai berikut:

1. Berdasarkan hasil penelitian ditemukan bahwa perolehan hasil Pajak Parkir di Kota Bitung dari tahun 2015 hingga tahun 2017 memberikan kontribusi yang sangat kecil 
dalam meningkatkan Pendapatan Asli Daerah Kota Bitung. Dapat dilihat dari target dan realisasi Pajak Parkir. Target Pajak Parkir berdasarkan APBD Induk tertinggi di Tahun 2017 sebesar Rp. 30.000.000 dan terendah di Tahun 2016 sebesar Rp. 15.000.000 sedangkan Target Pajak Parkir berdasarkan APBD Perubahan tertinggi di Tahun 2017 sebesar Rp. 35.000.000. Penetapan target Pajak Parkir dari Tahun 2015-2017 di iringi dengan ketercapaian reaisasi Pajak Parkir yang diterima. Dilihat dari segi jumlah realisasinya, Pendapatan Pajak Parkir tertinggi di Tahun 2017 mencapai Rp. 31.210.450, Pajak Parkir terendah di Tahun 2015 sebesar Rp. 22.932.900. Sedangkan, perolehan Pendapatan Asli Daerah Kota Bitung dari Tahun 2015-2017 mengalami kenaikkan dari tahun ke tahun. Pendapatan Asli Daerah tertinggi pada Tahun 2017 mencapai Rp. 71.210.450 dari total target dan realisasi Pendapatan Asli Daerah dan terendah pada tahun 2015 sebesar Rp. 37. 932. 900 dari total target dan realisasi Pendapatan Asli Daerah, dan untuk perolehan Pajak Daerah di Kota Bitung dari Tahun 2015-2017 selalu mengalami fluktuasi atau naik turun dari tahun ke tahun. Pendapatan Pajak Daerah tertinggi pada Tahun 2015 mencapai Rp. 69.710.100.176 dari total target dan realisasi Pajak Daerah dan terendah pada Tahun 2017 sebesar Rp. 53.240.870.245 dari total target dan realisasi Pajak Daerah.

2. Berdasarkan hasil penelitian ditemukan bahwa kontribusi Pajak Parkir terhadap Pendapatan Asli Daerah Kota Bitung dari Tahun 2015-2017 mengalami penurunan. Kontribusi tertinggi terjadi pada tahun 2015 yaitu sebesar 152,89\% dan kontribusi terendah terjadi pada tahun 2017 yaitu sebesar 89,17\%. penurunan kontribusi tersebut terjadi disebabkan oleh beberapa faktor yaitu dalam memenuhi peraturan perpajakan yang berlaku Wajib Pajak kurang memiliki pemahaman yang baik agar Wajib Pajak memiliki kesadaran untuk membayar pajak terutangnya, terdapat beberapa objek Pajak Parkir yang baru yang belum terdaftar sebagai Wajib Pajak Daerah, selain itu adanya pendapatan dari suatu tempat usaha yang pendapatannya tidak dapat diperkirakan sehingga tempat usaha tersebut tidak membayar pajak terutangnya.

3. Berdasarkan hasil penelitian objek Pajak Parkir di Kota Bitung antara lain : TK Girian Jaya, Kentucky Fried Chicken (KFC), RS. Budi Mulia, Centrepark Citiemart, dan Centrepark RSUD. Penetapan tarif Pajak Parkir sebesar $15 \%$ dan pembayarannya menggunakan Self Assesment system.

\subsection{Saran}

Berdasarkan kesimpulan diatas maka penulis mencoba mengutarakan beberapa saran bagi Badan Pengelola Pajak dan Retribusi Daerah Kota Bitung agar nantinya dapat menjadi bahan pertimbangan untuk dapat mengoptimalisasikan pendapatan dari sektor Pajak Parkir itu sendiri, diantaranya sebagai berikut:

1. Berdasarkan penelitian tersebut untuk meningkatkan jumlah Wajib Pajak Parkir di Kota Bitung, pihak Badan Pengelola Pajak dan Retribusi Daerah Kota Bitung memberikan usul agar petugas penagihan atas Pajak Parkir yang khusus ditugaskan di lapangan untuk diberikan penambahan supaya proses lebih efektif dan sesuai dengan sasaran yang ditetapkan.

2. Pihak Badan Pengelola Pajak dan Retribusi Daerah Kota Bitung sebaiknya meninjau langsung ke objek parkir yang belum terdaftar sebagai Pajak Parkir.

\section{DAFTAR PUSTAKA}

Budiarto, A. 2016. Pedoman Praktis Membayar Pajak. Genesis Learning. Yogyakarta. Debi, A. 2014. Analisis Efektivitas Pajak Parkir terhadap Pendapatan Asli Daerah 
Kota Mojokerto. Skripsi. Program Studi Ekonomi Akuntansi Universitas Negeri, Surabaya.

Erlina. 2016. Analisis Kontribusi Retribusi Parkir Terhadap Pendapatan Asli Daerah

Kota Makassar. Skripsi. Program Studi Ilmu Ekonomi Universitas Islam

Negeri Makassar.

Hery, 2013. Cara Mudah Memahami Akuntansi (Inti Sari Konsep Dasar Akuntansi). Prenada Media Group. Jakarta.

Hartono. 2017. Pengaruh Penerimaan Pajak Daerah Dan Retribusi Daerah Terhadap Peningkatan Pendapatan Asli Daerah Provinsi Daerah Istimewa

Yogyakarta (Periode 2012-2016). Skripsi. Program Studi Akuntansi Universitas PGRI Yogyakarta.

Havic. 2016. Analisis Penerimaan Retribusi Parkir dan Pajak Parkir di Dinas Pendapatan Asli Daerah Kota Palembang. Skripsi. Program Studi Akuntansi Sekolah Tinggi Ilmu Ekonomi Multi Data, Palembang.

Intan, K. 2016. Akuntansi Penerimaan Pajak Parkir Dan Retribusi Parkir Di Kabupaten Malang. Skripsi. Program Studi Ilmu Akuntansi Sekolah Tinggi Ilmu Ekonomi Indonesia, Surabaya.

Mahardika, P. 2017. Pengantar Akuntansi. Quadrant. Yogyakarta.

Mahmudah. 2014. Analisis Efektivitas Pajak Parkir terhadap Pendapatan Asli Daerah Kota Mojokerto. Skripsi. Program Studi Ekonomi Akuntansi Universitas Muhammadiyah, Malang.

Rosalina, A. 2016. Peran Pemungutan Pajak Parkir Dalam Peningkatan Pendapatan Asli Daerah di Kota Malang. Skripsi. Program Studi Administrasi Bisnis Universitas Brawijaya, Malang.

Woryandari. 2015. Analisis Efektifitas Pajak Parkir Terhadap Pendapatan Asli Daerah Kabupaten Sukaharjo. Skripsi. Program Studi Ekonomi Akuntansi Universitas Islam Batik, Surakarta.

Yohana. 2016. Kontribusi Pajak Parkir Dalam Meningkatkan Pendapatan Asli Daerah Kota Pontianak. Skripsi. Program Studi Pendidikan Ekonomi Universitas Tanjungpura, Pontianak. 